ISSN 2078-6441. Вісник Львівського університету. Серія географічна. 2013. Випуск 41. С. 273-281. Visnyk of the Lviv University. Series Geography. 2013. Issue 41. P. 273-281.

631.4:627.53 (477.81)

\author{
огд н видницький, рія сек \\ ьвівський н ціон льний університет імені в н \\ вул. . орошенк , 41, 79000, м. ввів, кр їн
}

озглянуто пит ння ерозійної дегр д ції т меліор тивного окультурення темно-сірих опідзолених легкосуглинкових грунтів ощ нського пл то. ведено дет льну х р ктеристику змін їхніх морфологічних озн к, фізичних т фізико-хімічних вл стивостей.

лючові слов : дегр д ція, окультурення, нтропогенн тр нсформ ція, меліор ція, оглеєння, осушення, ключові ділянки, коефіцієнт структурності, водостійкі грег ти.

емно-сірі опідзолені грунти в меж х ощ нського пл то перев ж ють, їх використовують головно як ріллю. они сформув лись н лесоподібних суглинк х під дубовогр бовими ліс ми з добре розвинутим тр в'янистим покривом в умов х сл бкохвилястих вододільних і вирівняних сл бкознижених форм рельєфу [8]. вдяки з ляг нню ч стин 3 них бул легкодоступною для сільськогоспод рського освоєння 3 ч сів княжої доби ( ст.). хнє освоєння н перших ет п х стримув ли умови з ляг ння н ерозійнонебезпечних схил $\mathrm{x}$ бо перезволожених зниженнях. роте щор з більші потреби в сільськогоспод рській продукції зумовлюв ли поступове розширення посівних площ з вдяки схиловим, пізніше й осушеним землям. н чне розширення посівних площ посилюв ло нтропогенну тр нсформ цію досліджув них грунтів, 3 н йбільшою інтенсивністю вон відбув л сь у період м ксим льного сільськогоспод рського освоєння під дією водноерозійних процесів т осушув льних меліор цій.

исленними дослідженнями [2-4, 6, 7, 9, 11 т ін.] 3'ясов но, що нтропогенн тр нсформ ція виявляється у змін х морфологічних, фізичних, водно-фізичних i фізико-хімічних вл стивостей грунтів. і зміни в різних грунт х і з різних умов м ють певні особливості.

шою метою було визн чення змін вл стивостей темно-сірих опідзолених легкосуглинкових грунтів ощ нського пл то під впливом процесів площинного змиву т осушув льних меліор цій.

ослідження проводили в осінній період н п'яти ключових ділянк x ( ) у меж х

ощ нецької сільської р ди строзького р-ну івненської обл., розт шов ної в південній ч стині ощ нського пл то. ибр н для дослідження територія $є$ х р ктерною для сл бкохвилястого ощ нського пл то івненської хвилясто-горбистої височини [8].

першій ключовій ділянці ( -1$)$ вивч ли вл стивості темно-сірих опідзолених глеюв тих легкосуглинкових грунтів, які сформув лись з умов вирівняного рельєфу.

і грунти, які використовув ли під ріллю, не з зн ли помітних змін, пов'яз них 3 водною ерозією. другій, третій і четвертій ключових ділянк х ( $-2, \quad-3, \quad-4)$, приурочених до розор них схилових земель, вивч ли, відповідно, вл стивості сл бко-, середньо- і сильнозмитих відмін досліджув них грунтів. орівнюючи вл стивості

(C) видницький ., сек ., 2013 
грунтів н цих ділянк х, виявляли зміни їх під впливом водноерозійних процесів, 3 умов інтенсивного нтропогенного н в нт ження.

п’ятій ключовій ділянці ( -5$)$, приуроченій до розор ного сл бковир женого мезозниження, вивч ли темно-сірі опідзолені глеюв ті осушені легкосуглинкові грунти. о осушення вони були глейовими, що виявлено н прилеглій неосушеній території. м же н дод ткових ключових ділянк х вивч ли їхні морфологічні вл стивості. ля х р ктеристики фізико-хімічних вл стивостей темно-сірих опідзолених глейових грунтів використ но результ ти н лізів 1970 р. [5].

процесі досліджень з стосовув ли порівняльно-геогр фічний, порівняльнопрофільний т порівняльно- н літичний методи. бор торно- н літичні роботи виконув ли з з г льноприйнятими метод ми [1] в л бор торії н лізу грунтів ьвівського н ціон льного університету імені в н $\mathrm{p}$ нк. икористовув ли т кож рхівні м тері ли грунтових обстежень 1993 р. івненської філії нституту землеустрою.

нтропогенн тр нсформ ція темно-сірих опідзолених легкосуглинкових грунтів ощ нського пл то в суч сних умов х виявил сь у дегр д ції т окультуренні. и вивч ли дегр д цію, пов'яз ну з водною ерозією, т окультурення, пов'яз не з гротехнічними і гідротехнічними меліор ціями. і процеси м ли різну трив лість т інтенсивність. егр д ційні процеси, пов'яз ні з водною ерозією, були трив лішими в ч сі й посилюв лись бо сповільнюв лись не тільки погодними умов ми в різні роки, й господ рською діяльністю з різних форм вл сності н землю [11]. собливо ктивно вони розвив лись у другій половині ст. 3 умов екстенсивного використ ння земель з численними порушеннями н уково обгрунтов них систем землеробств, зокрем , обробітку грунту, сівозмін т внесення добрив.

ослідженнями з'ясов но, що більшість розор них темно-сірих опідзолених глеюв тих легкосуглинкових грунтів ощ нського пл то н суч сному ет пі розвитку зн чно тр нсформов ні водноерозійними процес ми. з них сл бкозмитими є $30 \%$, середньозмитими -21 , сильнозмитими - $7 \%$. скільки площинний змив спричинений розорюв нням ерозійно небезпечних схилів т нехтув нням протиерозійними з ход ми, то його треб пов'язув ти з нтропогенною діяльністю.

емно-сірі опідзолені легкосуглинкові грунти вирівняних територій, які не підд ються дії водноерозійних процесів, з числено до нетр нсформов них. них орний ш $p$ потужністю 28-31 см збіг ється з гумусово-елюві льним горизонтом, його глибин 3 появою сл бких озн к оглеєння і присипки і 2 . ередня потужність гумусових горизонтів ( e+ i) досяг є $56 \mathrm{~cm}$, грунтотворн пород 3 ляг є 3 122-128 cм i збіг ється з глибиною з кип ння від 1 (див. т бл. 1). гр нулометричним скл дом це пилув то-піщ ні легкі суглинки 3 коефіцієнтом 3 г льної гр нулометричної диференці ції 1,7 і з кл сифік цією. оз нов н леж ть до сильнодиференційов них 3 елюві льно-ілюві льними озн к ми [10].

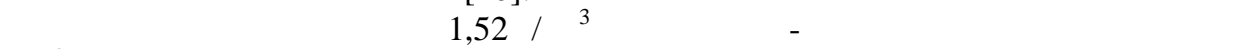

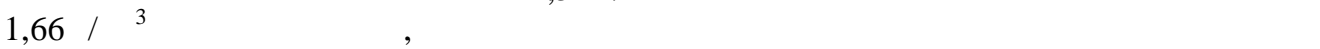
від 40,39 до 35,91 об. \%. оефіцієнт структурності в орному ш рі є з довільним $(0,71)$ i результ ти мокрого просіюв ння з свідчують незн чне перев ж ння $(56,42 \%)$ водостійких грег тів. изн чені з результ т ми сухого і мокрого просіюв ння пок зник водостійкості досяг є $135,6 \%$, коефіцієнт водостійкості 3 едвєдєвим 0,56 (див. т бл. 2). ні фізико-хімічних вл стивостей досліджув них грунтів, н ведені в т бл. 3, доводять, що вміст гумусу в орному ш рі колив ється в меж х 2,25-3,80\% і поступово зменшується до 0,58-0,86 \% в ілюві льному горизонті. е кція сольового 
розчину дещо підкислюється з глибиною і p сольове зменшується від 5,50-6,31 в орному ш рі до 5,10-5,40 в ілюві льному горизонті. ідролітичн кислотність у гумусових горизонт х не перевищує 2,24-2,30 ммоль/100 г грунту. ум увібр них основ в орному ш рі колив ється в меж х 9,80-14,60 ммоль/100 г грунту, ступінь н сичення основ ми - 81-88\%. гумусово-ілюві льному горизонті ці пок зники ч стково зменшуються, відповідно, до 9,02-12,00 ммоль/100 г грунту і 80-86 \%.

блиця 1

орфологічні озн ки темно-сірих опідзолених легкосуглинкових грунтів н лесоподібних суглинк х у меж х ощ нського пл то

\begin{tabular}{|c|c|c|c|c|c|c|c|c|c|c|c|}
\hline \multirow[b]{2}{*}{ 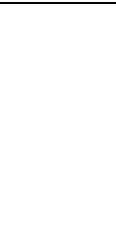 } & \multicolumn{7}{|c|}{ ижні межі генетичних горизонтів, см } & \multicolumn{3}{|c|}{ либин прояву, см } & \multirow{2}{*}{ 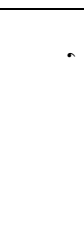 } \\
\hline & ठి & 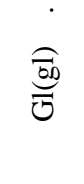 & $\begin{array}{l}\frac{0}{0} \\
00 \\
- \\
+\end{array}$ & $\underset{.0}{\stackrel{0.0}{0 .}}$ & $\begin{array}{l}+ \\
\stackrel{00}{0} \\
+0 \\
0\end{array}$ & $\begin{array}{l}\underset{0}{00} \\
\Xi \\
\equiv\end{array}$ & 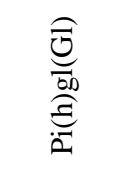 & 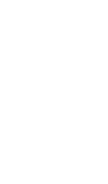 & 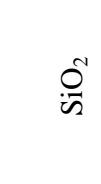 & 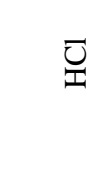 & \\
\hline $\begin{array}{r}\text { езмиті } \\
\text { глеюв ті }\end{array}$ & $\frac{28-31}{30}$ & - & - & $\frac{54-59}{56}$ & - & $\frac{82-87}{84}$ & $\frac{122-128}{124}$ & $\frac{28-31}{30}$ & $\frac{28-31}{30}$ & $\frac{122-128}{124}$ & 0 \\
\hline $\begin{array}{c}\text { л бко- } \\
\text { змиті } \\
\text { глеюв ті }\end{array}$ & - & - & $\frac{29-31}{30}$ & $\frac{47-50}{49}$ & - & $\frac{75-78}{77}$ & $\frac{116-118}{117}$ & $\begin{array}{r}\text { ліди } 3 \\
\text { поверх- } \\
\text { ні }\end{array}$ & $\begin{array}{r}\text { ліди } 3 \\
\text { поверх- } \\
\text { ні }\end{array}$ & $\frac{116-118}{117}$ & $\frac{4-12}{7}$ \\
\hline $\begin{array}{c}\text { еред- } \\
\text { ньозмиті } \\
\text { глеюв ті }\end{array}$ & - & - & $\frac{28-30}{29}$ & $\frac{33-40}{34}$ & - & $\frac{60-64}{62}$ & $\frac{100-107}{102}$ & $-/ /-$ & $\begin{array}{r}\text { по- } \\
\text { верхні }\end{array}$ & $\frac{100-107}{102}$ & $\frac{14-26}{22}$ \\
\hline $\begin{array}{c}\text { ильно- } \\
\text { змиті } \\
\text { глеюв ті }\end{array}$ & - & - & - & - & $\frac{28-30}{29}$ & - & $\frac{67-72}{69}$ & $\begin{array}{c}\text { по- } \\
\text { верхні }\end{array}$ & $\begin{array}{r}\text { по- } \\
\text { верхні }\end{array}$ & $\frac{67-71}{69}$ & $\frac{54-59}{55}$ \\
\hline $\begin{array}{r}\text { езмиті } \\
\text { глейові }\end{array}$ & - & $\frac{28-30}{29}$ & - & $\frac{47-56}{50}$ & - & $\frac{75-83}{81}$ & $\frac{135-141}{139}$ & $\begin{array}{c}\text { ильне } \\
\text { з по- } \\
\text { верхні }\end{array}$ & $\begin{array}{c}\text { по- } \\
\text { верхні }\end{array}$ & $\frac{135-141}{139}$ & 0 \\
\hline $\begin{array}{r}\text { езмиті } \\
\text { осушені } \\
\text { глеюв ті }\end{array}$ & - & $\frac{29-31}{30}$ & - & $\frac{52-60}{54}$ & - & $\frac{83-88}{85}$ & $\frac{120-134}{125}$ & $\begin{array}{l}\text { ліди з } \\
\text { поверх- } \\
\text { ні }\end{array}$ & $\begin{array}{c}\text { по- } \\
\text { верхні }\end{array}$ & $\frac{120-134}{125}$ & 0 \\
\hline
\end{tabular}

римітк : у чисельнику - колив ння пок зників;

у зн меннику - середні пок зники з семи визн чень.

емно-сірі опідзолені глеюв ті сл бкозмиті легкосуглинкові грунти, які з ляг ють н схил х 1-3 ${ }^{\circ}$, з числено до сл бкотр нсформов них. них змито від 4 до 12 см орного ш ру, що спричинило зменшення глибини з кип ння від L, вн слідок приорюв ння гумусово-ілюві льного горизонту в орному ш рі з'явились сліди оглеєння і присипк $\mathrm{SiO}_{2}$ (див. т бл. 1). н ліз гр нулометричного скл ду цих грунтів з свідчує збільшення в орному ш рі мулистої фр кції, як є причиною зменшення коефіцієнт 3 г льної гр нулометричної диференці ції грунтового профілю до 1,44.

орному ш рі підвищил сь щільність будови т знизил сь водостійкість грег тів, що зменшило його 3 г льну шп рув тість т погіршило структурно- грег тний ст н (див. т бл. 2). езульт ти фізико-хімічних н лізів свідч ть про зменшення вмісту гумусу, p сольового, суми увібр них основ, ступеня н сиченості основ ми т збільшення гідролітичної кислотності (див. т бл. 3). 
ізичні вл стивості темно-сірих опідзолених легкосуглинкових грунтів н лесоподібних суглинк х у меж х ощ нського пл то

\begin{tabular}{|c|c|c|c|c|c|c|c|c|c|c|c|c|c|c|c|}
\hline \multirow{3}{*}{ 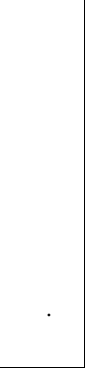 } & \multirow{3}{*}{ 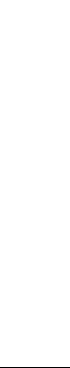 } & \multirow{3}{*}{ 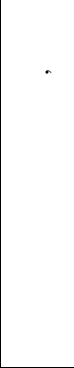 } & \multicolumn{2}{|c|}{$\begin{array}{c}\text { р нуломет- } \\
\text { ричний } \\
\text { скл д, \% }\end{array}$} & \multicolumn{3}{|c|}{$\begin{array}{l}\text { г льні фізичні } \\
\text { вл стивості }\end{array}$} & \multicolumn{8}{|c|}{ труктурно- грег тний скл д } \\
\hline & & & \multirow{2}{*}{ 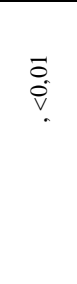 } & \multirow{2}{*}{ 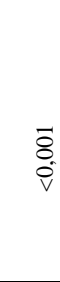 } & \multirow{2}{*}{ 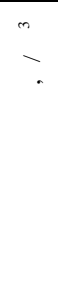 } & \multirow{2}{*}{ 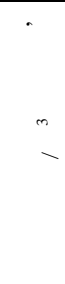 } & \multirow{2}{*}{ 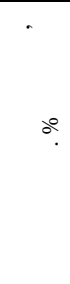 } & \multicolumn{4}{|c|}{ сухе просіюв ння, мм, \% } & \multicolumn{2}{|c|}{$\begin{array}{c}\text { мокре } \\
\text { просіюв н- } \\
\text { ня, мм, \% }\end{array}$} & \multirow{2}{*}{ 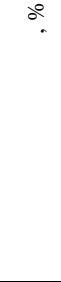 } & \multirow{2}{*}{ 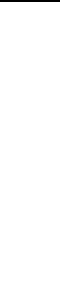 } \\
\hline & & & & & & & & $\frac{0}{\lambda}$ & $\begin{array}{l}n \\
1 \\
0 \\
0 \\
0\end{array}$ & 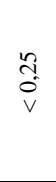 & 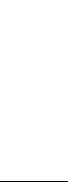 & 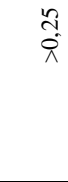 & 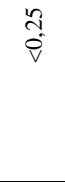 & & \\
\hline \multirow{3}{*}{ 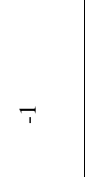 } & eop & $0-20$ & 22,76 & 3,88 & 1,52 & 2,51 & 40,39 & 58,27 & 41,61 & 0,12 & 0,71 & 56,42 & 43,58 & 135,6 & 0,56 \\
\hline & igl & $35-45$ & 22,95 & 4,74 & 1,58 & 2,59 & 39,00 & & & & & & & & \\
\hline & Ihgl & $60-70$ & 23,78 & 5,96 & 1,66 & 2,59 & 35,91 & & & & & & & & \\
\hline \multirow{3}{*}{ 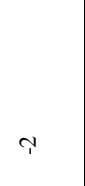 } & $\begin{array}{c}\mathrm{He}+ \\
\text { Higlop }\end{array}$ & $0-20$ & 22,68 & 4,12 & 1,59 & 2,56 & 37,89 & 59,52 & 40,37 & 0,11 & 0,68 & 51,58 & 48,42 & 127,8 & 0,52 \\
\hline & Higl & $35-45$ & 22,93 & 4,65 & 1,62 & 2,57 & 36,96 & & & & & & & & \\
\hline & Ihgl & $55-65$ & 23,95 & 5,68 & 1,66 & 2,58 & 35,66 & & & & & & & & \\
\hline \multirow{3}{*}{ 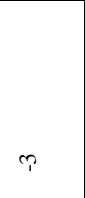 } & $\begin{array}{l}\text { He+ } \\
\text { Higlop }\end{array}$ & $0-20$ & 22,98 & 4,30 & 1,60 & 2,56 & 37,50 & 61,35 & 38,51 & 0,14 & 0,63 & 46,20 & 53,80 & 119,9 & 0,46 \\
\hline & Higl & $29-34$ & 23,14 & 4,80 & 1,63 & 2,58 & 36,82 & & & & & & & & \\
\hline & Ihgl & $45-55$ & 23,89 & 5,47 & 1,67 & 2,59 & 35,52 & & & & & & & & \\
\hline \multirow{2}{*}{ 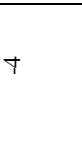 } & $\begin{array}{c}\text { He+ } \\
\text { Higl+ } \\
\text { Ihglop }\end{array}$ & $0-20$ & 23,08 & 4,92 & 1,61 & 2,56 & 37,10 & 69,07 & 30,78 & 0,15 & 0,44 & 25,40 & 74,60 & 82,5 & 0,25 \\
\hline & $\mathrm{Pi}(\mathrm{h}) \mathrm{gl}$ & $35-45$ & 24,02 & 5,12 & 1,60 & 2,58 & 37,98 & & & & & & & & \\
\hline \multirow{3}{*}{ 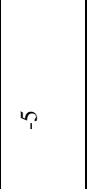 } & Heglop & $0-20$ & 22,97 & 4,02 & 1,54 & 2,58 & 40,31 & 55,15 & 44,72 & 0,13 & 0,81 & 63,26 & 36,74 & 141,5 & 0,63 \\
\hline & Higl & $35-45$ & 23,00 & 4,68 & 1,56 & 2,55 & 38,82 & & & & & & & & \\
\hline & Ihgl & $65-75$ & 23,66 & 5,62 & 1,64 & 2,59 & 36,68 & & & & & & & & \\
\hline
\end{tabular}

иявлені зміни морфологічних, фізичних і фізико-хімічних вл стивостей у сл бкозмитих грунт х є незн чними, що д є підст ву з числити їх до сл бкотр нсформов них.

меншити бо н віть припинити нег тивну тр нсформ цію можн, удоскон ливши гротехніку вирощув ння зон льних сільськогоспод рських культур, увівши новітні технології, збільшивши дози орг но-мінер льних добрив т удоскон ливши системи сівозмін. 
ізико-хімічні вл стивості темно-сірих опідзолених легкосуглинкових грунтів н лесоподібних суглинк х у меж х ощ нського пл то

\begin{tabular}{|c|c|c|c|c|c|c|c|}
\hline \multirow{2}{*}{ 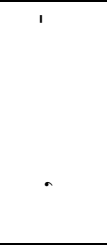 } & \multirow{2}{*}{ 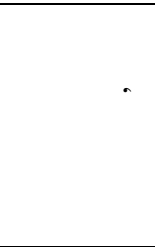 } & \multirow{2}{*}{ 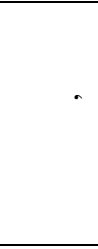 } & \multirow{2}{*}{$\begin{array}{l}0 \\
0 \\
0 \\
\text { है } \\
0 \\
0\end{array}$} & \multirow[t]{2}{*}{$\sum_{i}^{\infty}$} & $\begin{array}{c}\text { ум } \\
\text { увібр них } \\
\text { основ }\end{array}$ & $\begin{array}{c}\text { ідролі- } \\
\text { тичн } \\
\text { кислот- } \\
\text { ність }\end{array}$ & \multirow{2}{*}{ 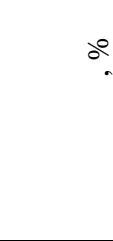 } \\
\hline & & & & & \multicolumn{2}{|c|}{ ммоль/100г грунту } & \\
\hline \multirow{3}{*}{ 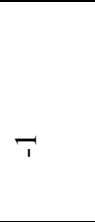 } & $\begin{array}{r}\text { e op } \\
0-30\end{array}$ & $0-20$ & $\frac{5,50-6,31}{5,96}$ & $\frac{2,25-3,80}{3,02}$ & $\frac{9,88-14,60}{12,66}$ & $\frac{1,68-2,30}{2,00}$ & $\frac{81-88}{85}$ \\
\hline & $\begin{array}{c}\text { i gl } \\
30-56 \\
\end{array}$ & $35-45$ & $\frac{5,42-5,80}{5,60}$ & $\frac{1,52-2,10}{1,83}$ & $\frac{9,02-12,0}{10,59}$ & $\frac{1,73-2,24}{2,02}$ & $\frac{80-86}{84}$ \\
\hline & $\begin{array}{c}\text { Ihgl } \\
56-84\end{array}$ & $60-70$ & $\frac{5,10-5,40}{5,20}$ & $\frac{0,58-0,86}{0,70}$ & - & - & - \\
\hline \multirow{3}{*}{ 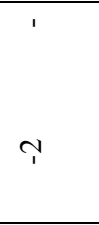 } & $\begin{array}{c}\mathrm{He}+\mathrm{Hi} \mathrm{gl} \mathrm{op} \\
0-30\end{array}$ & $0-20$ & $\frac{5,31-5,84}{5,63}$ & $\frac{2,04-2,50}{2,26}$ & $\frac{8,12-13,05}{10,73}$ & $\frac{1,80-2,28}{2,04}$ & $\frac{79-88}{84}$ \\
\hline & $\begin{array}{c}\text { Hi gl } \\
30-49\end{array}$ & $35-45$ & $\frac{5,20-5,61}{5,40}$ & $\frac{1,50-1,94}{1,76}$ & $\frac{8,00-11,20}{9,32}$ & $\frac{1,96-2,28}{2,14}$ & $\frac{78-86}{81}$ \\
\hline & $\begin{array}{c}\text { Ihgl } \\
49-77\end{array}$ & $55-65$ & $\frac{4,90-5,40}{5,20}$ & $\frac{0,50-0,80}{0,66}$ & - & - & - \\
\hline \multirow{3}{*}{ 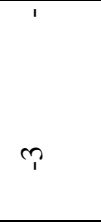 } & $\begin{array}{c}\mathrm{He}+\mathrm{Hi} \text { gl op } \\
0-29\end{array}$ & $0-20$ & $\frac{5,10-5,50}{5,29}$ & $\frac{1,40-2,00}{1,72}$ & $\frac{7,91-11,63}{9,50}$ & $\frac{2,16-2,56}{2,34}$ & $\frac{75-84}{80}$ \\
\hline & $\begin{array}{c}\text { Hi gl } \\
29-34\end{array}$ & $29-34$ & $\frac{5,18-5,40}{5,25}$ & $\frac{1,39-1,86}{1,70}$ & $\frac{7,20-9,81}{8,50}$ & $\frac{2,32-2,66}{2,49}$ & $\frac{74-80}{77}$ \\
\hline & $\begin{array}{c}\text { Ihgl } \\
34-62\end{array}$ & $45-55$ & $\frac{4,90-5,20}{5,11}$ & $\frac{0,40-0,78}{0,62}$ & - & - & - \\
\hline \multirow{2}{*}{ 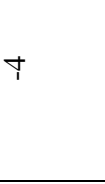 } & $\begin{array}{c}\mathrm{He}+\mathrm{Hi} \mathrm{gl}+ \\
\text { Ihgl op } \\
0-29 \\
\end{array}$ & $0-20$ & $\frac{4,80-5,32}{5,00}$ & $\frac{0,74-0,90}{0,81}$ & $\frac{6,18-8,12}{7,15}$ & $\frac{2,45-2,75}{2,58}$ & $\frac{69-77}{73}$ \\
\hline & $\begin{array}{l}\text { Pi(h)gl } \\
29-68 \\
\end{array}$ & $35-45$ & $\frac{4,66-5,00}{4,80}$ & $\frac{0,30-0,41}{0,34}$ & $\frac{5,72-6,41}{6,00}$ & $\frac{2,48-2,82}{2,62}$ & $\frac{64-71}{66}$ \\
\hline 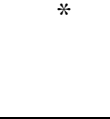 & $\begin{array}{l}\text { e opGl } \\
0-30\end{array}$ & $0-20$ & $\frac{4,80-6,80}{6,30}$ & $\frac{1,01-2,18}{1,63}$ & $\frac{1,40-36,60}{14,34}$ & $\frac{0,26-3,81}{1,45}$ & $\frac{73-98}{84}$ \\
\hline \multirow{3}{*}{ 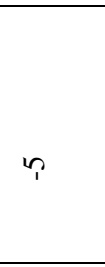 } & $\begin{array}{c}\text { Hegl op } \\
0-30\end{array}$ & $0-20$ & $\frac{5,52-6,86}{6,38}$ & $\frac{1,98-3,00}{2,70}$ & $\frac{10,40-18,96}{14,45}$ & $\frac{1,13-2,00}{1,43}$ & $\frac{80-96}{86}$ \\
\hline & $\begin{array}{c}\text { Hi gl } \\
30-60\end{array}$ & $35-45$ & $\frac{5,20-5,70}{5,50}$ & $\frac{1,60-2,00}{1,69}$ & $\frac{9,32-12,10}{10,42}$ & $\frac{1,70-}{\frac{2,64}{2,14}}$ & $\frac{81-85}{82}$ \\
\hline & $\begin{array}{c}\text { Ihgl } \\
60-86\end{array}$ & $65-75$ & $\frac{5,00-5,20}{5,08}$ & $\frac{0,56-0,80}{0,66}$ & - & - & - \\
\hline
\end{tabular}

римітки: у чисельнику - колив ння пок зників, у зн меннику - середні пок зники із трьох, * - д ні н лізів 1970 р. [5].

емно-сірі опідзолені глеюв ті середньозмиті легкосуглинкові грунти сп дистих схилів, у яких змито пон д $70 \%$ гумусово-елюві льного горизонту, з числено до середньотр нсформов них. н слідок приорюв ння зн чної ч стини гумусовоілюві льного горизонту в орному ш рі з'явились ірж ві т вохристі плями і рясн 
присипк $\mathrm{SiO}_{2}$ (див. т бл. 1). гр нулометричному скл ді мулист фр кція рівномірно розподілен між генетичними горизонт ми. оефіцієнт з г льної гр нулометричної диференці ції грунтового профілю зменшився до 1,33 і профіль ст в середньодиференційов ним з елюві льно-ілюві льними озн к ми. лизьких зн чень у меж х профілю н були щільність будови і з г льн шп рув тість. труктур в орному ш рі ст л пилув то-горіхув то-брилув тою, коефіцієнт водостійкості з едведєвим знизився м йже н $20 \%$ порівняно з незмитими грунт ми (див. т бл. 2). міст гумусу зменшився м йже н половину в орному ш рі й ч стково в підорному горизонті. них т кож зн чно підвищил сь гідролітичн кислотність т знизились зн чення суми ввібр них основ, ступеня н сиченості основ ми і р сольового (див. т бл. 3). к б чимо, середньозмиті грунти з вл стивостями зн чно гірші від незмитих. они суттєво погіршилися під впливом водноерозійних процесів, посилених господ рською діяльністю, і тому з числені до середньотр нсформов них. од льше використ ння їх у сільськогоспод рському виробництві можливе лише в умов х грунтоз хисних сівозмін, які зд тні припинити нег тивну тр нсформ цію і зумовити позитивні зміни.

емно-сірі опідзолені глеюв ті сильнозмиті грунти, що з ляг ють н схил х 5-12 3 числено до сильнотр нсформов них. хньою х р ктерною особливістю є змитість гумусово-елюві льного й гумусово-ілюві льного горизонтів т розорюв ння сл бкогумусов ного ілюві льного горизонту. орному ш рі є тільки з лишки гумусових горизонтів, ірж ві і вохристі плями т рясн присипк $\mathrm{SiO}_{2} \mathrm{H}$ д ють йому коричневобурого з б рвлення з білув тим відтінком. н слідок змиву грунтотворн к рбон тн пород н близил сь до поверхні в середньому н 55 см (див. т бл. 1).

езульт том змитості є т кож те, що пок зники гр нулометричного скл ду і з г льних фізичних вл стивостей в орному ш рі т підорному горизонті (Pi(h)Gl) н близились 3 зн ченнями. труктур в орномуш рі ст л пилув то-брилув тою, результ ти мокрого просіюв ння з свідчують, що лише четверт ч стин грег тів $є$ водостійкою. оефіцієнт водостійкості з едведєвим у 2,24 р з нижчий, ніж у незмитих (див. т бл. 2). н слідок сильної змитості зменшились вміст гумусу в орному ш рі у 3,7 p 3 , сум увібр них основ - в 1,8 р 3 , ступінь н сичення основ ми - в 1,2 p 3 . підорному горизонті ці пок зники зменшились відповідно у 5,4, 1,7 т 1,3 p 3 . н слідок приорюв ння горизонтів з нижчими зн ченнями р сольового кислотність в орному ш рі змінил сь із близької до нейтр льної н середньокислу (див. т бл. 3). p нсформ ція цих грунтів пов'яз н 3 дегр д цією і зумовлен дуже високим нтропогенним н в нт женням т прискореними темп ми водноерозійних процесів, тому тільки консерв ція їх зн чно посл бить дегр д цію і створить сприятливі умови для відновлення природних процесів грунтоутворення.

емно-сірі опідзолені глейові легкосуглинкові грунти ун слідок проведення меліоp тивних з ходів поліпшув ли свої вл стивості, т кож тепловий, кислотний т поживний режими, тобто з зн в ли окультурюв ння. езміненими вони з лишились тільки н природних кормових угіддях, де м ють сильне оглеєння т присипку $\mathrm{Si}{ }_{2}$ в поверхневих горизонт х (див. т бл. 1).

гротехнічні меліор ції н темно-сірих опідзолених глейових грунт х, які передб ч ли розорюв ння т ч сті розпушув ння орного ш ру, т кож внесення добрив і меліоp нтів поліпшув ли водно-повітряний режим тільки в орному ш рі. рний ш р тр нсформув вся із глейового у глеюв тий, підорні горизонти, як і грунт з г лом, 3 лишились глейовими. період розорюв ння фізико-хімічні вл стивості орного ш ру поліпшув лись тільки в умов х високої культури землеробств . ведені в т бл. 3 пок зники 
фізико-хімічних вл стивостей розор них глейових грунтів колив ються в досить широких ді п зон х, що підтверджує неодн кові умови розвитку суч сних процесів грунтоутворення. стин із них з лишил сь пр ктично без змін, тобто не з зн л тр нсформ ції. роте більшість поліпшил свої вл стивості в орному ш рі, у якому пок зники фізико-хімічних вл стивостей н близились до осушених глеюв тих, що д $€$ підст ви з числити їх до сл бкотр нсформов них гротехнічними меліор ціями.

ідротехнічні меліор ції створили умови для поліпшення ер ції темно-сірих опідзолених глейових грунтів н глибину осушення, под льші громеліор тивні 3 ходи позитивно вплинули н їхні фізичні й фізико-хімічні вл стивості. оліпшення ер ції зменшило оглеєння і зумовило тр нсформ цію глейових грунтів у глеюв ті. еріодичні в пнув ння кислих грунтів, внесення орг но-мінер льних добрив, уведення в сівозміни однорічних і 6 г торічних тр в, що передб чене громеліор тивними з ход ми, створили умови для підвищення вмісту гумусу, мінім льних зн чень p сольового, суми увібр них основ, ступеня н сиченості основ ми т зниження м ксим льних зн чень гідролітичної кислотності (див. т бл. 3). кі позитивні зміни, що відбулись 3 40-50 років, д ють підст ви з числити темно-сірі опідзолені глеюв ті осушені легкосуглинкові грунти до середньотр нсформов них гідротехнічними й гротехнічними меліор ціями. роте нехтув ння в жливими принцип ми гротехнічних i меліор тивних 3 ходів т доглядом 3 осушув льною мережею в ост нні 10-15 років зн чно посл били процеси окультурення осушених земель і в б г тьох вип дк х спричинили зворотну тр нсформ цію, тобто регр д цію бо повернення до природного процесу розвитку в умов х стійкого перезволоження.

тже, дослідженням з'ясов но, що нтропогенн тр нсформ ція пов'яз н як 3 дегр д цією, т к і з окультуренням. собливості їі поляг ють у тому, що темно-сірі опідзолені глеюв ті грунти н розор них схил х тр нсформув лись тільки в н прямі дегр д ції, меліоров ні глейові н вирівняних сл бкознижених форм х рельєфу у н прямі окультурення, яке може змінюв тись регр д цією. егр д цію спричинили водно-ерозійні процеси, окультурення - гротехнічні т гідротехнічні меліор ції.

умови сл бкохвилястого рельєфу виявлено нетр нсформов ні т сл бко-, середньо- і сильнотр нсформов ні водно-ерозійними процес ми грунти. умов х вирівняних знижень визн чено сл бко- і середньотр нсформов ні гротехнічними т гідротехнічними меліор ціями окультурені грунти, т кож грунти, які після нетрив лого окультурення регр дують ун слідок виходу з л ду окремих ч стин осушув льної мережі.

е $з$ зн ли нтропогенної тр нсформ ції 39 \% темно-сірих опідзолених глеюв тих легкосуглинкових грунтів. они м ють н йліпші морфологічні озн ки і н йсприятливіші фізичні т фізико-хімічні вл стивості для вирощув ння більшості зон льних сільськогоспод рських культур.

л бкої водноерозійної тр нсформ ції з зн л третин глеюв тих грунтів, які з ляг ють н похилих $\left(1-3^{\circ}\right)$ схил х і були незн чно змінені. меншити чи припинити водноерозійні процеси можуть прогресивні методи обробітку грунту т вдоскон лення сівозмін.

ередньої водноерозійної тр нсформ ції з зн ли пон д $20 \%$ досліджув них глеюв тих грунтів. них змито до $75 \%$ гумусово-елюві льного горизонту і м йже н половину зменшено вміст гумусу в орному ш рі, т кож суттєво погіршено інші вл стивості. і грунти приурочені до схилів $3-5^{\circ}$ і под льше використ ння їх у сільськогоспод рському виробництві можливе лише в грунтоз хисних сівозмін х. 
ильнотр нсформов ні водноерозійними процес ми близько $7 \%$ темно-сірих опідзолених глеюв тих грунтів, приурочених до схилів 5-12 . н слідок змитості гумусово-елюві льного і гумусово-ілюві льного горизонтів розорюють сл бкогумусов ний ілюві льний горизонт із нез довільними фізичними і фізико-хімічними вл стивостями. од льш дегр д ція цих грунтів припиняється тільки вн слідок консерв ції.

л бкоокультурені темно-сірі опідзолені глейові легкосуглинкові грунти тр пляються дрібними контур ми (до $10 \%$ ) серед розор них темно-сірих опідзолених глеюв тих. они з зн ли незн чних змін ун слідок розорюв ння і поліпшили свої вл стивості тільки н глибину ор нки.

ередньоокультурені темно-сірі опідзолені глеюв ті осушені легкосуглинкові грунти приурочені до вирівняних знижень і до проведення гідротехнічних т гротехнічних меліор цій були глейовими. еліор тивні з ходи зн чно поліпшили їхні вл стивості і тепер близько 80 \% із них використовують як високопродуктивні орні землі.

егр дов ні грунти розвив ються н осушених м сив х ун слідок вторинного з болочення в р зі виходу з л ду окремих ч стин осушув льної мережі. они з ост нні 1015 років, після нетрив лого окультурення меліор тивними з ход ми, знову ст ли глейовими.

\section{СПИСОК ВИКОРИСТАНОЇ ЛІТЕРАТУРИ}

1. лекс ндров . . бор торно-пр ктические з нятия по почвоведению / . . лекс ндров , . . йденов . - . : олос, 1967. - 351 с.

2. ндрущенко . . рунти з хідних обл стей / . . ндрущенко. - ьвів; убляни : ільн кр їн , 1970.-181 с.

3. ознюк . уч сний ст н вивчення проблеми 3 плив ння грунтів т утворення кірки і результ ти їх дослідження н грунт х івненської обл сті / . ознюк, . ичук // енез , геогр фія т екологія грунтів. - ьвів : ид в. центр імені в н $\mathrm{p}$ нк , 2003. - .65-69.

4. ознюк . . ритерії оптиміз ції природно-меліор тивного режиму осушув них земель / . . ознюк, . . окочинський // грохімія і грунтозн вство. пец. випуск. - рків: гр рн н ук, 1998. - .3. - .113-115.

5. в $ш$. рунти івненської обл сті / в ш .- ьвів : меняр, 1970. - 97 с.

6. оротун . . мін грунтового покриву під впливом гідротехнічних меліор цій н території івненської обл сті / . . оротун // грохімія і грунтозн вство. пец. випуск. - рків: гр рн н ук , 1998. - .3. - .129-131.

7. ерезволожені грунти т їх меліор ція / [3 ред. . . ознюк ]. - . : рож й, 1984. - $103 \mathrm{c}$.

8. рирод овенської обл сті/[з ред. . . еренчук ]. - ьвів : ид-во ьвів. ун-ту, 1976. - $156 \mathrm{c}$.

9. щевлоцький . рунти ок льського п см і їх нтропогенн тр нсформ ція / . шевлоцький, . ськевич. - ьвів: ид в. центр імені в н $\mathrm{p}$ нК , 2002. $-178 \mathrm{c}$.

10. оз нов . . орфология почв / . . оз нов. - . : зд-во оск. ун-т , 1983. $320 \mathrm{c}$. 
11. видницький . нтропогенн тр нсформ ція темно-сірих опідзолених глеюв тих грунтів хідного ісостепу / . видницький, . еглівець // енез, геогр фія т екологія грунтів. - ьвів: ид в. центр імені в н р нк, 2008. . 462-467.

\title{
ANTROPOGENIC TRANSFORMATION FEATURES OF DARK GREY PODZOLIK LIGHT LOAMY SOILS OF GOSHCHANSKE PLATEU
}

\section{Bohdan Svydnytskyi, Maria Paseka}

Ivan Franko National University of Lviv, Doroshenko St., 41, UA - 79000 Lviv, Ukraine

The task of soil erosion degradation and melioration cultivation of dark grey podzolic light loamy soils of Goshchanske plateu was lighted. Detailed description of changes in their morphological traits physical and physico-chemical properties has been conducted.

Key words: degradation, cultivation, anthropogenius transformation, melioration, gleization, drainage, key plats, structural coefficient, water-resistant aggregates.

\author{
огд н видницкий, рия сек \\ ввовский н цион льный университет имени в н \\ ул. орошенко, 41, 79000, г. ввов, кр ин
}

ссмотрено вопрос эрозионной дегр д ции и мелиор тивного окультурив ния темно-серых оподзоленных легкосуглинистых почв ощ нского пл то. риведено дет льную х р ктеристику изменений их морфологических призн ков, физических и физико-химических свойств.

лючевые слов : дегр д ция, окультурив ние, нтропогенн я тр нсформ ция, мелиор ция, оглеив ние, осушение, ключевые уч стки, коэффициент структурности, водопрочные грег ты. 